\title{
The Role of Diet as an Adjuvant Treatment in Scarring and Nonscarring Alopecia
}

\author{
Christine T. Pham ${ }^{a}$ Karina Romero ${ }^{b}$ Hind M. Almohannac Jacob Griggs ${ }^{d}$ \\ Azhar Ahmed $^{\mathrm{d}}$ Antonella Tosti $^{\mathrm{d}}$ \\ ${ }^{a}$ Department of Dermatology, University of California Irvine, Irvine, CA, USA; b Dermatology Service, Clinica \\ Angloamericana, Lima, Peru; ' ${ }^{2}$ epartment of Dermatology and Dermatologic Surgery, Prince Sultan Military \\ Medical City, Riyadh, Saudi Arabia; ${ }^{d}$ Dr. Phillip Frost Department of Dermatology and Cutaneous Surgery, \\ University of Miami, Miami, FL, USA
}

\section{Keywords}

Diet · Alopecia $\cdot$ Hair loss $\cdot$ Nutrition

\begin{abstract}
Background: Diet is known to affect a wide range of health disorders. Many patients with hair and scalp diseases often inquire about special diets that may improve their symptoms. Objective: To evaluate nutrition and diet as adjunct treatments in nonscarring and scarring alopecia. Methods: A primary literature search using PRISMA guidelines was conducted using the PubMed database in October 2019. Results: Twenty-four articles with 1,787 patients were included. The Mediterranean diet, which is rich in raw vegetables and fresh herbs, and isoflavone-rich soy contain anti-inflammatory nutrients that may promote hair health and growth in androgenetic alopecia (AGA). The gluten-free diet was shown to stimulate hair growth in alopecia areata (AA) patients with concomitant celiac disease, though no effect was seen with a lactose-free diet. Sufficient protein was found to be necessary for hair health. The human chorionic gonadotropin diet, hypocaloric diet, and increased fish, buckwheat, and millet groats consumption were possible triggers of alopecias such as AGA, AA, telogen effluvium, or frontal fibrosing alopecia. Limitations: This review was limited by the lack
\end{abstract}

\section{KARGER}

(c) 2020 S. Karger AG, Basel

karger@karger.com

www.karger.com/sad of studies and controls. Conclusion: The Mediterranean diet as well as diets rich in protein and soy may be potential adjunct therapeutics for the treatment of nonscarring alopecias. The use of diets in alopecia treatment regimens warrants further exploration.

(c) 2020 S. Karger AG, Basel

\section{Introduction}

The emerging popularity of anti-inflammatory diets has garnered interest in its use as a potential therapeutic in reducing inflammation in autoimmune conditions. Alopecia areata (AA) and many scarring alopecias such as lichen planopilaris are autoimmune conditions that can be recalcitrant and difficult to manage. Chronic inflammation can cause loss of barrier function, sensitivity to a normally benign stimulus, infiltration of inflammatory cells into compartments where they do not belong, and overproduction of oxidants, cytokines, chemokines, eicosanoids, and matrix metalloproteinases [1]. These resultant symptoms can be destructive and contribute to clinical symptoms. Restricting patients to a diet that minimizes inflammation can alter expression of inflammatory genes, perhaps affecting chronic disease, and acting as a basic gene-silencing tech- 
Fig. 1. Flowchart depicting the PRISMA search algorithm used for this systematic review.

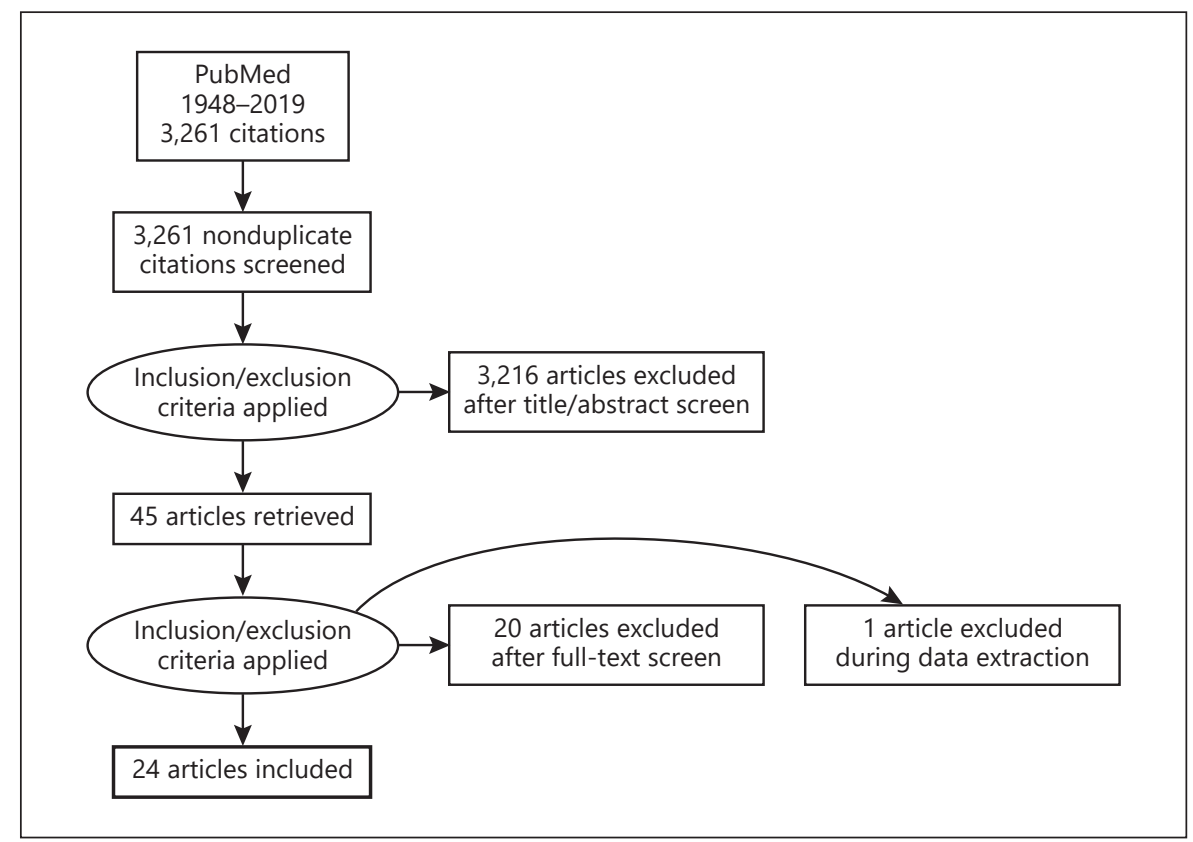

nique [2]. The success of anti-inflammatory agents in the management of these autoimmune alopecias suggests that an anti-inflammatory diet may also be a successful strategy for improving patient outcomes.

The role of the microbiome in AA has been of recent interest. A study by Nair and Christiano [3] showed that mice given antibiotics were protected from the development of AA. Gut bacteria may degrade the intestinal epithelial barrier leading to inflammation and autoimmunity, highlighting the possibility that changes in diet may influence the gut microbiota. Two young men with alopecia universalis and Clostridium difficile infection with/ without Crohn's disease, both refractory to steroid injections, were given a fecal microbiota transplant to treat C. difficile. After the fecal microbiota transplant and two intralesional steroid injections, significant regrowth was seen on the scalp and other body parts such as the face and arms [4]. These cases emphasize the importance of the gut microbiota in alopecia.

However, the importance of diet may not be limited to autoimmune hair disorders. A key pathophysiological feature of androgenetic alopecia (AGA) includes overactivation of $5 \alpha$-reductase which increases androgen levels, leading to increased reactive oxygen species in the dermal papilla cells and secretion of transforming growth factor $\beta_{1}$ which inhibits hair growth [5]. Polyphenols, compounds found in plant substances that have antioxidant properties, were found to inhibit $5 a$-reductase, suggesting a potential role for diets in AGA treatment [6]. Fur-

Role of Diet as Adjuvant Treatment in Scarring and Nonscarring Alopecia thermore, telogen effluvium (TE) is a stress-induced, transient alopecia that has been found to be triggered by extreme diet restrictions.

The potential application of diets as an adjunct treatment for alopecia highlights a different modality for dermatologists to provide anti-inflammatory treatments. The aim of this review is to assess the effects of nutrition and diet on scarring and nonscarring alopecia.

\section{Materials and Methods}

A primary literature search using the Preferred Reporting Items for Systematic Reviews and Meta-Analyses (PRISMA) guidelines was conducted using the PubMed database in October 2019 with the search terms: "alopecia," "hair," "androgenetic alopecia," "lichen planopilaris," "frontal fibrosing alopecia," "alopecia areata," "diet," "nutrition," "western diet," "Mediterranean diet," "ketogenic diet," "paleo diet," "gluten-free diet," "vegan diet," and "vegetarian diet." Inclusion criteria comprised any type of dietary substance and assessment of the effects on human subject hair. Exclusion criteria were animal and basic science studies and supplements. Strength of clinical data was graded using the Oxford Center Levels of Evidence-Based Medicine 2011.

\section{Results}

The primary literature search identified 3,261 articles that were screened based on title and abstract. Forty-five articles were subjected to full-text screen (Fig. 1). Twenty- 
Table 1. Summary of the association of diets with nonscarring and scarring alopecia

\begin{tabular}{llll}
\hline Author & $\begin{array}{l}\text { Study type (quality } \\
\text { level) }\end{array}$ & Demographics & Outcome \\
\hline
\end{tabular}

Androgenetic alopecia

Lai et al. [7],

Case-control study (4) 354 M AGA and 354 controls

Fortes et al. [8]

2017

Cross-sectional study

(2)

351 Caucasian patients $(237 \mathrm{M}, 114 \mathrm{~F})$, mean age 35.6 years; mild AGA: 237 , moderate AGA: 114
Soybean drink consumption

ruits/vegetables, protein wine, beer, spirits or liquorous wine consumption
Regular soybean drinkers (at least 1-3 days/week) had an OR of 0.04 for developing moderate to severe AGA $(p=0.04)$; frequent consumption of soybean drinks ( 3 days/week) may be protective against moderate to severe AGA

Consumption of fruits/vegetables (low: $89.5 \%$, high: 10.5\%); protein foods (low: $86.8 \%$, high: $13.2 \%$ ); wine (low: $78.6 \%$, high: $21.4 \%$ ); beer (low: $45.3 \%$, high: $54.7 \%$ ); spirits or liquorous wine (low: $45.3 \%$, high: $54.7 \%$ ); no difference was found for high consumption of fruits and vegetables and consumption of protein foods; high consumption of wine was associated with AGA severity (OR: 1.75; 95\% CI: 1.04-2.96); no increased risk was associated with beer, spirits, or liquorous wine

Fortes et al. [9], Case-control study (4) $104 \mathrm{M}$ and 108 controls, mean age: Mediterranean diet 2018 28.5 and 38.9 years

Multivariate model: protective effects were found with high consumption ( $\geq 3 \times$ weekly) of raw vegetables and fresh herbs $(\geq 3)$; the regular use of sage and rosemary was borderline associated with a protective effect; subjects consumin $\geq 3 \times$ weekly raw vegetables and fresh herbs had half the risk of developing AGA compared to $<2 \times$ weekly raw vegetables or not regularly using fresh herbs

\begin{tabular}{|c|c|c|c|c|}
\hline $\begin{array}{l}\text { Griggs et al. [12], } \\
2018\end{array}$ & Case report (5) & Male in his $30 \mathrm{~s}$ & $\begin{array}{l}\text { hCG diet ( } 500 \text { calories/day } \\
\text { and hCG injections) with } \\
\text { testosterone hormone pellet }\end{array}$ & 1-year follow-up: AGA developed \\
\hline $\begin{array}{l}\text { English and Barazesh } \\
{[10], 2019}\end{array}$ & Retrospective study (3) & 296 M, 29 F, 2 unreported & $\begin{array}{l}\text { Comparison of vegan/vege- } \\
\text { tarian versus paleo diet with } \\
\text { American diet as reference in } \\
\text { addition to twice-daily, 20-min } \\
\text { standardized scalp massages }\end{array}$ & $\begin{array}{l}\text { Plant-based (vegan/vegetarian) diets had a positive trend towards self-perceived } \\
\text { hair changes }(p=0.08) \text { versus a standard American diet, and no effect for a paleo } \\
\text { diet }(p=0.66)\end{array}$ \\
\hline $\begin{array}{l}\text { Garg and Sangwan } \\
{[11], 2019^{*}}\end{array}$ & $\begin{array}{l}\text { Cross-sectional study } \\
\text { (2) }\end{array}$ & $\begin{array}{l}20 \text { AGA males, } 11 \text { AGA females } \\
(+8 \mathrm{TE}, 3 \mathrm{AA})\end{array}$ & $\begin{array}{l}\text { Protein deficiency } \\
\text { Impact of breakfast }\end{array}$ & $\begin{array}{l}90 \% \text { of AGA patients were deficient in protein, } 55 \% \text { of male AGA and } 90.9 \% \text { of } \\
\text { female AGA were severely deficient ( }<30 \text { g/day protein), most had high carbohy- } \\
\text { drate/fat diet; scalp biopsy from the low-protein group showed perifollicular } \\
\text { chronic inflammatory infiltrate and fibrosis, the high-protein group showed } \\
\text { normal follicular structure; patients eating breakfast on time had better protein } \\
\text { intake than those who delayed or missed breakfast; deficient protein intake, } \\
\text { missing breakfast, and unhealthy lifestyle increased the onset and severity of AGA }\end{array}$ \\
\hline
\end{tabular}

Alopecia areata

Corazza et al. [13], Case series (4)

Patient 1: 27-year-old F with AA

Gluten-free diet

Patient 2: 38-year-old $M$ with AU

Patient 4: 29-year-old F with AU

Patient 5: 15-year-old M with AU

Patient 6: 19-year-old F with

patchy AA

All have celiac disease

Patient 1: 6-month follow-up: normalization of celiac symptoms; couple years' follow-up: $2 / 3 \mathrm{AA}$ patches disappeared

Patient 2: poor compliance with diet

Patient 3: 1-year follow-up: complete regrowth of hair, eyebrows, and eyelashes:

3-year follow-up: situation unchanged

3-year follow-up: situation unchanged
Patient 4: 1-year follow-up: complete regrowth of eyelashes and eyebrows, initial regrowth of pubic and underarm hair regrowth of pubic and

Patient 6: poor compliance with diet

\begin{tabular}{|c|c|c|}
\hline $\begin{array}{l}\text { Volta et al. [14], } \\
1997\end{array}$ & Case series (4) & $\begin{array}{l}\text { Patient 1: Young F with AU } \\
\text { Patient 2: Elder F with patchy AA, } \\
\text { autoimmune thyroiditis } \\
\text { All have celiac disease }\end{array}$ \\
\hline
\end{tabular}

Gluten-free diet

Patient 1: 6-month follow-up: partial regrowth of scalp and other body hair

Patient 2: 3-month follow-up: no improvement

Barbato et al. [15], Case series (4) Patient 1: 21-year-old F with AA

1998 Patient 2: 26-year-old F with AA

All have celiac disease

Gluten-free diet

Patient 1: 6-month follow-up: new hair growth despite lack of general and local pharmacological treatment, normalization of celiac symptoms

2-year follow-up: no recurrence of AA

Patient 2: 6-month follow-up: new hair growth, normalization of celiac symptom 1-year follow-up: AA patches completely disappeared

2-year follow-up: no recurrence

\begin{tabular}{|c|c|c|c|c|}
\hline $\begin{array}{l}\text { Bondavelli et al. [16], } \\
1998\end{array}$ & Case report (5) & $\begin{array}{l}\text { Patient 1: } 32 \text {-year-old F with AU } \\
\text { Patient 2: Brother with AA } \\
\text { All have celiac disease }\end{array}$ & Gluten-free diet & $\begin{array}{l}\text { Patient 1: 4-year follow-up: no improvement in AA, normalization of celiac } \\
\text { symptoms } \\
\text { Patient 2: 4-year follow-up: AA worsened, normalization of celiac symptoms } \\
\text { 4-year and 2-month follow-up: AA improved spontaneously }\end{array}$ \\
\hline $\begin{array}{l}\text { Bardella et al. [17], } \\
2000\end{array}$ & Case series (4) & $\begin{array}{l}\text { Patient 1: } 34 \text {-year-old F with } \\
\text { patchy AA } \\
\text { Patient 2: } 39 \text {-year-old F with AU } \\
\text { Patient 3: 46-year-old F with } \\
\text { patchy AA } \\
\text { Patient 4: } 26 \text {-year-old M with AU } \\
\text { Patient 5: } 30 \text {-year-old F with } \\
\text { patchy AA } \\
\text { All have celiac disease }\end{array}$ & Gluten-free diet & $\begin{array}{l}\text { Patient 1: few months' follow-up: complete regrowth of hair, eyelashes, and } \\
\text { eyebrows; 2-year follow-up: AU appeared with improvement but patchy pattern } \\
\text { still present, normalization of celiac symptoms } \\
\text { Patient 2: 6-month follow-up: normalization of celiac symptoms } \\
\text { 3-year follow-up: no effect on AU } \\
\text { Patient 3: 8-month follow-up: patchy AA still evident, normalization of celiac } \\
\text { symptoms } \\
\text { Patient 4: 1-year follow-up: normalization of celiac symptoms } \\
\text { 30-month follow-up: no effect on AU } \\
\text { Patient 5: 2-year follow-up: no effect on AA, normalization of celiac symptoms }\end{array}$ \\
\hline $\begin{array}{l}\text { Naveh et al. [18], } \\
1999\end{array}$ & Case series (4) & $\begin{array}{l}\text { Patient 1: 16-year-old F with AU } \\
\text { Patient 2: } 26 \text {-month-old F with AA } \\
\text { Patient 3: } 18 \text {-month-old M with AA } \\
\text { All have celiac disease }\end{array}$ & $\begin{array}{l}\text { Gluten-free diet, lactose-free } \\
\text { diet }(n=2)\end{array}$ & $\begin{array}{l}\text { Patient 1: 5-month follow-up: no hair regrowth on lactose-free diet, hair regrowth } \\
\text { with gluten-free diet; 2-year follow-up: impressive hair regrowth } \\
\text { Patient 2: 1-month follow-up: no effect on AA; 2-month follow-up: complete } \\
\text { regrowth of hair in left temporal region } \\
\text { Patient 3: hair loss progression worsened on lactose-free diet; 10-month follow- } \\
\text { up: complete regrowth of hair }\end{array}$ \\
\hline $\begin{array}{l}\text { Viola, et al. [19], } \\
1999\end{array}$ & Case report (5) & $\begin{array}{l}\text { 21-year-old F with AA and celiac } \\
\text { disease }\end{array}$ & Gluten-free diet & $\begin{array}{l}\text { 6-month follow-up: hair regrowth } \\
\text { 2-year follow-up: developed AA because she ate gluten }\end{array}$ \\
\hline
\end{tabular}


Table 1 (continued)

\begin{tabular}{|c|c|c|c|c|}
\hline Author & $\begin{array}{l}\text { Study type (quality } \\
\text { level) }\end{array}$ & Demographics & Diet & Outcome \\
\hline $\begin{array}{l}\text { Storm }[20] \\
2000\end{array}$ & Case report (5) & $\begin{array}{l}\text { 9-year-old F with AA, celiac disease, } \\
\text { and Down syndrome }\end{array}$ & Gluten-free diet & $\begin{array}{l}\text { 5-month follow-up: hair regrowth } \\
\text { 8-month follow-up: no recurrence of AA }\end{array}$ \\
\hline $\begin{array}{l}\text { Fessatou et al. [21], } \\
2003\end{array}$ & Case series (4) & $\begin{array}{l}\text { 13-year-old F with AA } \\
29 \text {-month-old F with AA } \\
\text { All have celiac disease }\end{array}$ & Gluten-free diet & $\begin{array}{l}\text { Patient 1: 1-year follow-up: complete regrowth of hair, normalization of celiac } \\
\text { symptoms } \\
\text { Patient 2: 9-month follow-up: continued hair regrowth }\end{array}$ \\
\hline $\begin{array}{l}\text { Guariso et al. [21], } \\
2007\end{array}$ & Prospective study (3) & 2 children with AA, celiac disease & Gluten-free diet & 17- and 26-month follow-up: hair regrowth and complete remission \\
\hline $\begin{array}{l}\text { Ertekin et al. [23] } \\
2014\end{array}$ & Prospective study (3) & $\begin{array}{l}4 \mathrm{~F}, 1 \mathrm{M} \text {, all pediatric patients with } \\
\text { AA and celiac disease, age range: } \\
3-17 \text { years }\end{array}$ & Gluten-free diet & Complete hair growth \\
\hline $\begin{array}{l}\text { Garg and Sangwan } \\
{[11], 2019^{*}}\end{array}$ & $\begin{array}{l}\text { Cross-sectional study } \\
\text { (2) }\end{array}$ & $\begin{array}{l}3 \mathrm{AA} \\
(+20 \text { AGA,11 female AGA, } 8 \text { TE) }\end{array}$ & $\begin{array}{l}\text { Protein deficiency } \\
\text { Impact of breakfast }\end{array}$ & $\begin{array}{l}\text { AA patients were deficient in protein and missing or delayed breakfast; scalp } \\
\text { biopsy from low-protein group showed perifollicular chronic inflammatory } \\
\text { infiltrate and fibrosis, high-protein group showed normal follicular structure; } \\
\text { patients eating breakfast on time had better protein intake than those who missed } \\
\text { or delayed breakfast }\end{array}$ \\
\hline $\begin{array}{l}\text { Peters and Warren } \\
{[24], 2019^{*}}\end{array}$ & Case series (4) & 43-year-old perimenopausal F & Daily ingestion of grilled tuna & $\begin{array}{l}\text { Sudden loss of hair in circular pattern on left side of scalp } \\
\text { 2-month follow-up: hair regrowth after stopping the ingestion of fish } \\
\text { 7-month follow-up: complete hair regrowth }\end{array}$ \\
\hline
\end{tabular}

\section{Telogen effluvium}

Telogen effluvium

Kaufman [25], $\quad$ Case report [5] 20-year-old F
1976

Hypocaloric, low-carbohydrate TE onset diet (starvation diet)

Goette and Odom $\quad$ Case series (4) Patient 1: 29-year-old F

[26], $1976 \quad$ Patient 2: 33-year-old F

Patient 3: 50-year-old $M$

Patient 4: 33-year-old F

Patient 5: 25-year-old F

Patient 6: 29-year-old F

Patient 7: middle-ald $\mathrm{F}$

Patient $7:$ iddle-aged

Patient 8: 20-year-old F
Patient 9: 26-year-old F

Pat

\section{Patient 1: 4-week hypocaloric weight reduction program with daily hCG injections for 3} months

Patient 2: 500-calorie starva-

tion diet for 10 weeks

Patient 3: hypocaloric and

exercise program

exercise program
Patient 4: 6-month hypocaloric

Patient 4: 6-month hypocaloric
diet

diet

Patient 5: 5-month 1,000-calo-

rie diet with diet pills

Patient 6: 4-month hypocaloric

diet with daily hCG injections

Patient 7: hypocaloric diet with

hCG injections for several

months

Patient 8: 200-calorie/day diet

Patient 8: 200-calorie/day diet

day diet with hCG injections

\begin{tabular}{|c|c|c|c|c|}
\hline $\begin{array}{l}\text { Krusinski [27], } \\
1976\end{array}$ & Case report (5) & 36-year-old F & $\begin{array}{l}\text { Hypocaloric, low-carbohydrate } \\
\text { diet (starvation diet) }\end{array}$ & TE onset \\
\hline $\begin{array}{l}\text { Perez-Mora et al. [28], } \\
2014\end{array}$ & Retrospective study (3) & $\begin{array}{l}197 \text { F AGA } \\
306 \text { non-F AGA }\end{array}$ & Severe diet & $\begin{array}{l}\text { Triggered acute TE in } 7.1 \% \text { of female AGA and } 4.5 \% \text { of nonfemale AGA; severe } \\
\text { diet has a OR of } 10.6 \text { in triggering acute TE in female AGAs }\end{array}$ \\
\hline $\begin{array}{l}\text { Garg and Sangwan } \\
{[11], 2019^{*}}\end{array}$ & $\begin{array}{l}\text { Cross-sectional study } \\
\text { (2) }\end{array}$ & $\begin{array}{l}8 \mathrm{TE},(+20 \text { AGA males, } 11 \mathrm{AGA} \\
\text { females, } 3 \mathrm{AA})\end{array}$ & $\begin{array}{l}\text { Protein deficiency, } \\
\text { Impact of breakfast }\end{array}$ & $\begin{array}{l}75 \% \text { of TE patients were severely deficient ( }<30 \mathrm{~g} / \text { day protein); scalp biopsy from } \\
\text { low-protein group showed perifollicular chronic inflammatory infiltrate and } \\
\text { perifollicular fibrosis, high-protein group showed normal follicular structure; } \\
\text { breakfast eaters had higher protein intake than breakfast missers and late eaters; } \\
\text { onset of hair loss was reported to occur due to decreased dietary consumption } \\
\text { (e.g., crash diets, postpartum period, or stress) }\end{array}$ \\
\hline $\begin{array}{l}\text { Peters and Warren } \\
{[24], 2019^{*}}\end{array}$ & Case series (4) & 39-year-old perimenopausal F & No unusual diet & $\begin{array}{l}\text { Diffuse hair loss with elevated } \mathrm{Hg} \text { levels }(29 \mu \mathrm{g} / \mathrm{L}) \text {, suggested to stop fish intake } \\
\text { 5-month follow-up: some improvement in alopecia with decrease in } \mathrm{Hg} \text { to } 11 \\
\mu \mathrm{g} / \mathrm{L} \\
\text { 1-year follow-up: worsening of alopecia with } \mathrm{Hg} \text { level of } 43 \mu \mathrm{g} / \mathrm{L} \\
\text { 6-month follow-up: Hg levels lowered from } 21 \text { to } 10 \mu \mathrm{g} / \mathrm{L} \text {, improvement in } \\
\text { alopecia } \\
\text { 1-year follow-up: hair regrowth }\end{array}$ \\
\hline
\end{tabular}

Lichen planopilaris/frontal fibrosing alopecia

$\begin{array}{lll}\text { Rudnicka and } & \text { Case-control study (4) } & 59 \mathrm{~F} \text { with FFA and } 59 \mathrm{~F} \text { controls }\end{array}$ Buckwheat and millet groats

FFA patients consumed buckwheat and millet groats at least twice weekly in the recent 3 months compared to controls ( 81.4 vs. $30.5 \%, p<0.01$ ); no statistical significance found with regard to eating meat, fish, vegetables, fruits, and drinking coffee or alcohol

\begin{tabular}{|c|c|c|c|c|}
\hline $\begin{array}{l}\text { Moreno-Arrones et } \\
\text { al. [30], } 2019\end{array}$ & Case-control study (4) & $\begin{array}{l}308 \text { FFA }(289 \mathrm{~F}, 19 \mathrm{M}) \text { and } 347 \\
\text { controls }(289 \mathrm{~F}, 58 \mathrm{M})\end{array}$ & $\begin{array}{l}\text { Soy products, herbs/spices, } \\
\text { and grapes }\end{array}$ & $\begin{array}{l}\text { Soy consumption: } 10 \% \text { FFA vs. } 14.5 \% \text { control, } p=0.10 \\
\text { Herb/spice consumption: } 39.4 \% \text { FFA vs. } 33.2 \% \text { control, } p=0.11 \\
\text { Grape consumption: } 13.5 \% \text { FFA vs. } 8.7 \% \text { control, } p=0.06\end{array}$ \\
\hline
\end{tabular}

F, female, M, male; AGA, androgenetic alopecia; AA, apecia a asterisk indicates repeated studies due to patient sample containing multiple alopecia diagnoses.
Role of Diet as Adjuvant Treatment in Scarring and Nonscarring Alopecia 
one articles were excluded because they were animal, basic science, or supplement studies. Twenty-four articles, which consisted of 4 case-control studies, 2 cross-sectional studies, 2 prospective studies, 2 retrospective studies, 9 case series, and 5 case reports, were included in this review. Case reports were kept in the review as they may detect novelties that can be important in a field that has been scarcely studied. These articles comprised an aggregate of 1,787 patients (1,019 males, 722 females, 46 unknown) (Table 1). Diets include the Mediterranean diet, paleo diet, vegetarian/vegan diet, gluten-free diet, lactose-free diet, human chorionic gonadotropic (hCG) diet, hypocaloric diet; food groups include fruits, vegetables, protein; food and nutrient items include soy, herbs/ spices, grapes, fish, alcohol, buckwheat, and millet groats.

\section{Androgenetic Alopecia}

Five studies and 1 case report analyzed the effects of the Mediterranean, vegan/vegetarian, paleo, or hCG diet, protein-rich breakfast, or consumption of fruits, vegetables, soy, and alcohol on AGA [7-12]. One patient developed AGA after 1 year on the hCG diet (an ultra-lowcalorie diet combined with hCG injections), followed by testosterone hormone pellet implantation [12].

A case-control study with 354 randomly selected Taiwanese males and matched controls evaluated the efficacy of isoflavone-rich soybean drinks in AGA. A selfadministered questionnaire was given to participants to collect information on lifestyle factors such as eating habits. Frequent consumption of soybean drinks ( 3 days per week) was associated with a $77 \%$ decrease in the risk of AGA. It was concluded that it may provide protective effects against moderate to severe AGA. Frequent consumption of coffee, dairy milk, and cheese did not show any protective effect [7].

The diets of 351 Caucasian subjects (237 mild AGA, 114 moderate AGA) were analyzed in a cross-sectional survey by Fortes et al. [8] in 2017. The majority of AGA patients reported low consumption of fruits/vegetables $(89.5 \%)$, protein $(86.8 \%)$, and wine $(78.6 \%)$. No significant association was found between AGA severity and consumption of fruits/vegetables, protein, beer, spirits, or liquorous wine, although high consumption of wine $(\geq 3$ times weekly) was associated with AGA severity [8].

Recently Fortes et al. [9] directly looked at the impact of the Mediterranean diet in a case-control study with 104 AGA patients and 108 controls. The multivariable model results showed high intake ( $\geq 3$ times weekly) of raw vegetables and fresh herbs ( 3 or more types regularly) may be protective for AGA. The regular use of sage and rosemary showed a positive association though results were not significant. High consumption of cooked vegetables, cruciferous vegetables, leafy green vegetables, and tomatoes showed possible protective effects for AGA in the univariate model [9].

Protein intake levels and the impact of breakfast were analyzed in a cross-sectional study with 98 patients which included those with AGA ( $n=20$ males, $n=11$ females). A total of $90 \%$ of male AGA patients were deficient in proteins $(<50 \mathrm{~g} /$ day $)$, with $55 \%$ of these males and $90.9 \%$ of female AGA with severe deficiency ( $<30 \mathrm{~g} /$ day). Scalp biopsies performed on the low protein group showed perifollicular chronic inflammatory infiltrate and fibrosis, whereas the high protein group showed normal follicles. Patients who ate breakfast in the morning had higher protein intake and less cutaneous and hair problems than patients who missed breakfast or ate later, implicating the significance of the circadian rhythm. It was concluded that protein deficiency, missing breakfast, and an unhealthy lifestyle possibly increased the onset and severity of AGA [11].

A retrospective survey study investigated whether secondary parameters such as diet in addition to scalp massages played a role in treating AGA. Patients were surveyed to determine whether a plant-based (vegetarian or vegan) or paleo diet had an effect on their hair. With the standard American diet as reference, the plant-based diet had a positive correlation with perceived benefits to the scalp with borderline statistical significance $(p=0.08)$; however, the paleo diet did not $(p=0.66)$ [10].

\section{Alopecia Areata}

Thirteen articles analyzed the gluten-free diet, lactosefree diet, protein levels, and breakfast consumption, and mercury-rich fish intake on AA [11, 13-24].

Two prospective studies, 6 case series, and 3 case reports analyzed the effects of the gluten-free diet $(n=31$, in 2 cases combined with the lactose-free diet) on AA patients with a concomitant diagnosis of celiac disease [13$23]$. Out of the 31 reported AA patients given a glutenfree diet, $70.9 \%$ showed improvement, $22.6 \%$ did not improve, and $6.5 \%$ had no compliance with the diet; all patients experienced normalization of celiac symptoms as well. Of those patients who improved, $68.2 \%$ had patchy AA, $13.6 \%$ had alopecia universalis, $4.5 \%$ had alopecia totalis, while the rest of the AA cases (13.6\%) were unspecified. Hair regrowth on the scalp, eyebrows, and eyelashes occurred as early as 2 months with no recurrence of AA in follow-ups up to 3 years. A 6-month-old female and 18-month-old male received a temporary lac-
Pham/Romero/Almohanna/Griggs/ Ahmed/Tosti 
tose-free diet that improved celiac symptoms but did not improve hair loss until the gluten-free diet was added [18].

Garg and Sangwan [11] analyzed 98 patients $>15$ years old who attended a clinic in India for various skin and hair disorders in a cross-sectional study and found severely deficient dietary protein levels (10-30 g/day) and delayed breakfast schedules in all 3 patients with AA. Peters and Warren [24] reported a 43-year-old perimenopausal female who developed an alopecic patch after daily tuna intake. Hair regrowth occurred 2 months after discontinuation of fish consumption, with complete growth observed by 7 months.

\section{Telogen Effluvium}

Six articles analyzed protein intake levels and breakfast consumption, hypocaloric diets, and mercury-rich fish in TE [11, 24-28]. A cross-sectional study by Garg and Sangwan [11] looked at $8 \mathrm{TE}$ patients and found that $75 \%$ were severely deficient in protein $(<30 \mathrm{~g} /$ day), and a few patients reported onset of alopecia occurring after reduced nutritional consumption associated with crash diets, postpartum period, or stress. One retrospective study, 1 case series, and 2 case reports found that a hypocaloric low-carbohydrate starvation diet with or without hCG injections triggered TE. In a retrospective study with 197 female AGA patients and 306 controls, a severe diet was found to have an odds ratio of 10.6 in triggering acute TE in patients with female AGA when compared to seasonal hair loss [28].

One case series reported a 39-year-old perimenopausal female who developed a 3-year history of diffuse alopecia with elevated mercury $(\mathrm{Hg})$ levels $(29 \mu \mathrm{g} / \mathrm{L})$, despite denying any unusual diets. Discontinuing fish intake was recommended. Hg levels were sporadically checked within the next 2 years and alopecia severity was found to correlate with higher $\mathrm{Hg}$ levels. Alopecia improved 5 months after stopping fish consumption, with normalization of hair growth reported in an 18-month follow-up [24].

\section{Lichen Planopilaris/Frontal Fibrosing Alopecia}

Specific studies about the influence of diet in lichen planopilaris are not reported; however, there are 2 studies regarding diet and frontal fibrosing alopecia (FFA) [29, 30]. A case-control study from Poland evaluated the dietary habits in 59 FFA females and age-matched controls. A total of $81.4 \%$ of FFA patients reported a statistically increased consumption of buckwheat and millet groats at least twice weekly compared to $30.5 \%$ of controls in the prior 3 months. No statistically significant differences were found regarding consumption of meat, fish, vegetables, fruits, coffee, or alcohol [29].

A multicenter case-control study surveyed 664 females (335 FFA, 329 controls) and 106 males (20 FFA, 86 controls) regarding diet factors at least 5 years prior to the onset of the disease. No significant difference was observed between the two groups with regard to weekly consumption of phytoestrogens (soy products), herbs/spices, and grapes, though an increase in grape consumption was observed in healthy controls (13.5\% compared to $8.7 \%$ FFA patients; $p=0.06$ ) [30].

\section{Discussion}

The role of diets as adjunct treatments in alopecia is a question that patients commonly inquire about. The Mediterranean diet and isoflavone-rich soy contain antiinflammatory nutrients that may promote hair health and growth in AGA. The gluten-free diet has been shown to stimulate hair growth in AA patients with concomitant celiac disease, though no effect was seen with a lactosefree diet. High mercury-rich fish consumption may trigger AA and TE, and high buckwheat and millet groats consumption was found to be associated with FFA in a study.

Consistent with the role of inflammation in the pathogenesis of AGA, it makes intuitive sense that a diet rich in antioxidant, anti-inflammatory, or estrogenic components - properties found in the Mediterranean diet could prevent hair loss. These plant-rich diets contain phytochemicals, such as carotenoids and polyphenols, with anti-inflammatory and antioxidant properties which can reduce the production of reactive oxygen species in the dermal papilla cells, leading to the reduced secretion of transforming growth factor $\beta_{1}$ and stimulation of hair growth [31-33]. Some polyphenols (e.g., flavonoids like apigenin and myricetin) have estrogenic activities which can inhibit $5 a$-reductase activity $[6,34]$. One case-control study found that high consumption of raw vegetables and fresh herbs was protective against AGA, and a retrospective study found that AGA patients perceived a plantbased diet to positively impact their scalp, thus providing evidence for its recommendation $[9,10]$.

Isoflavones, a phytoestrogen with significant levels in soy products, have high antioxidant and estrogen-like activities [35]. Isoflavone supplements have been shown to increase insulin growth factor-1, a stimulator of hair follicle proliferation [36]. One case-control study with 354 Taiwanese males and matched controls found that fre- 
quent consumption of soy bean drinks are associated with protective effects against moderate to severe AGA $[7,36]$.

Proteins are the major components of hair. A crosssectional study found severe protein intake deficiencies in Indian AGA, AA, and TE patients, supporting protein as an essential nutrient for hair. In an analysis of the protein content of major Indian food items, fish such as codfish, tuna, and salmon had the most protein content per portion. Though fish is regularly eaten in the Mediterranean diet, caution is recommended as 2 patients developed alopecia from $\mathrm{Hg}$ intoxication due to high levels of tuna and other mercury-rich fish consumption [24].

Recent research has pointed to the increasing significance of the microbiota in inflammatory conditions. Short-chain fatty acids have anti-inflammatory effects through the regulation of T cells and interleukin-10. The western diet which contains higher amounts of processed foods and fat, and lower fiber content leading to lower amounts of short-chain fatty acids and altered gut bacteria - provides an environment that is more prone to inflammation [37]. The full regrowth of hair found after fecal microbiota transplant in two patients with AA support the importance of the gut microbiome in AA [4]. Celiac disease is associated with AA; both contain organspecific autoantibodies and show T-lymphocyte infiltration and association with HLA genes. One study found that the short-chain fatty acid pattern in pediatric celiac disease normalized after a gluten-free diet for 1 year [38]. All AA patients who improved after a gluten-free diet had celiac disease, suggesting that the removal of gluten not only calmed down the inflammation and normalized the gut microbiota, but also positively impacted the scalp. Most of these patients had patchy AA rather than more severe disease states such as alopecia universalis and alopecia totalis, which could explain why more improved outcomes were observed.

There is scarce literature on the role of diets in scarring alopecia. One study showed an association between buckwheat and millet groats consumption in FFA patients, suggesting a potential role in its pathogenesis [29]. However, both are antioxidant-rich nutrient sources as buckwheat contains high concentrations of flavonoids while millets constitute a major source of phenolic acids and micronutrients [39]. Phytochemical-rich foods should theoretically be advantageous in inflammatory alopecia conditions such as FFA, though another study also found no significant difference in weekly consumption of herbs/ spices, phytoestrogens (i.e., soy), or natural peroxisome proliferator-activated receptor $\mathrm{C}$ agonists (i.e., grapes) between FFA versus control [30]. More large-scale stud- ies are needed to delineate the role of diets in scarring alopecias.

Processed foods contain a variety of chemical additives such as phthalates, which make plastics flexible and durable, and bisphenols, which are used in epoxy resins and polycarbonate plastics. Exposure to these chemicals can be harmful, especially in children, due to their ability to disrupt the endocrine system and its association with precocious puberty $[40,41]$. In a cross-sectional study by Buckley et al. [40], ultra-processed food consumption was associated with increased urinary phthalate concentration while consumption of minimally processed foods was associated with lower concentrations of phthalates and bisphenols. Based on these results, consumption of fresh foods in the diet may reduce the exposure to these harmful chemicals.

\section{Conclusions}

The current literature demonstrates the potential for anti-inflammatory diets as an adjunct therapy in alopecia disorders. Diets that include fresh vegetables, soy, and protein promote hair growth and may be protective against AGA, AA, and TE. Preliminary results show that the gluten-free diet may be an effective treatment for AA patients with celiac disease. AGA may be triggered by the hCG diet, AA and TE by high consumption of mercury-rich fish, and TE by the hypocaloric diet. Furthermore, increased consumption of buckwheat and millet groats was found to be associated with FFA. Though limitations of this review include lack of studies and controls, the therapeutic potential of diets warrants larger-scale clinical trials to confirm the efficacy in alopecia.

\section{Acknowledgment}

We would like to thank the American Hair Research Society, the University of Miami, Dr. Phillip Frost Department of Dermatology and Cutaneous Surgery, and the University of California Irvine, Department of Dermatology for providing the opportunity and resources to carry out this research.

\section{Statement of Ethics}

The attached paper is previously unpublished and is not currently under consideration for publication in any other journals.
Pham/Romero/Almohanna/Griggs/ Ahmed/Tosti 


\section{Disclosure Statement}

Conflicts of interest for Dr. Antonella Tosti: Consultant P\&G, DS Laboratories, Monat, Thirty Madison. Principal investigator: Incyte, Lilly, Aclaris, Nutrafol.

\section{Funding Sources}

The authors received no funding to complete this research.

\section{Author Contributions}

All authors, Christine T. Pham, Karina Sandoval, Hind M. Almohanna, Azhar Ahmed, Jacob Griggs, and Antonella Tosti, have taken part in writing, editing, and reading the attached paper and agree with its content.

\section{References}

1 Calder PC, Albers R, Antoine JM, Blum S, Bourdet-Sicard R, Ferns GA, et al. Inflammatory disease processes and interactions with nutrition. Br J Nutr. 2009 May;101(S1 Suppl 1):S1-45.

2 Sears B. Anti-inflammatory Diets. J Am Coll Nutr. 2015;34(sup1 Suppl 1):14-21.

3 Nair L, Dai Z, Christiano AM. Gut microbiota plays a role in the development of alopecia areata. J Invest Dermatol. 2017;137(5):112. https://doi.org/10.1016/j.jid.2017.02.671.

4 Rebello D, Wang E, Yen E, Lio PA, Kelly CR. Hair Growth in Two Alopecia Patients after Fecal Microbiota Transplant. ACG Case Rep J. 2017 Sep;4(1):e107.

5 Eun HC, Woo SM. The involvement of ROS on androgen inducible TGF beta 1 regulation derived from dermal papilla cells: a suggestive implication of ROS on androgenetic alopecia. J Am Acad Dermatol. 2008 Feb;58(2):84.

6 Hiipakka RA, Zhang HZ, Dai W, Dai Q, Liao S. Structure-activity relationships for inhibition of human 5alpha-reductases by polyphenols. Biochem Pharmacol. 2002 Mar;63(6): 1165-76.

7 Lai CH, Chu NF, Chang CW, Wang SL, Yang HC. Androgenic alopecia is associated with less dietary soy, higher blood vanadium and rs1160312 1 polymorphism in Taiwanese communities. PLoS One. 2013 Dec; 8(12):e79789.

8 Fortes C, Mastroeni S, Mannooranparampil TJ, Ribuffo M. The combination of overweight and smoking increases the severity of androgenetic alopecia. Int J Dermatol. 2017 Aug;56(8):862-7.

9 Fortes C, Mastroeni S, Mannooranparampil T, Abeni D, Panebianco A. Mediterranean diet: fresh herbs and fresh vegetables decrease the risk of Androgenetic Alopecia in males. Arch Dermatol Res. 2018 Jan;310(1):71-6.

10 English RS Jr, Barazesh JM. Self-Assessments of Standardized Scalp Massages for Androgenic Alopecia: survey Results. Dermatol Ther (Heidelb). 2019 Mar;9(1):167-78.

11 Garg S, Sangwan A. Dietary protein deficit and deregulated autophagy: a new clinico-diagnostic perspective in pathogenesis of early aging, skin, and hair disorders. Indian Dermatol Online J. 2019 Mar-Apr;10(2):115-24.
12 Griggs J, Almohanna H, Ahmed A, Tosti A. New-onset androgenic alopecia following human chorionic gonadotropic diet and testosterone pellet implantation. Int J Trichol. 2018 Nov-Dec;10(6):284-5.

13 Corazza GR, Andreani ML, Venturo N, Bernardi M, Tosti A, Gasbarrini G. Celiac disease and alopecia areata: report of a new association. Gastroenterology. 1995 Oct;109(4): 1333-7.

14 Volta U, Bardazzi F, Zauli D, DeFranceschi L, Tosti A, Molinaro N, et al. Serological screening for coeliac disease in vitiligo and alopecia areata. Br J Dermatol. 1997 May;136(5):8012.

15 Barbato M, Viola F, Grillo R, Franchin L, Lo Russo L, Lucarelli S, et al. Alopecia and coeliac disease: report of two patients showing response to gluten-free diet. Clin Exp Dermatol. 1998 Sep;23(5):236-7.

16 Bondavalli P, Quadri G, Parodi A, Rebora A. Failure of gluten-free diet in celiac diseaseassociated alopecia areata. Acta Derm Venereol. 1998 Jul;78(4):319.

17 Bardella MT, Marino R, Barbareschi M, Bianchi F, Faglia G, Bianchi P. Alopecia areata and coeliac disease: no effect of a gluten-free diet on hair growth. Dermatology. 2000;200(2): 108-10.

18 Naveh Y, Rosenthal E, Ben-Arieh Y, Etzioni A. Celiac disease-associated alopecia in childhood. J Pediatr. 1999 Mar;134(3):362-4.

19 Viola F, Barbato M, Formisano M, Premate FM, Lucarelli S, Frediani T, et al. [Reappearance of alopecia areata in a coeliac patient during an unintentional challenge with gluten]. Minerva Gastroenterol Dietol. 1999 Dec; 45(4):283-5.

20 Storm W. Celiac disease and alopecia areata in a child with Down's syndrome. J Intellect Disabil Res. 2000 Oct;44(Pt 5):621-3.

21 Fessatou S, Kostaki M, Karpathios T. Coeliac disease and alopecia areata in childhood. J Paediatr Child Health. 2003 Mar;39(2):152-4.

22 Guariso G, Conte S, Presotto F, Basso D, Brotto F, Visonà Dalla Pozza L, et al. Clinical, subclinical and potential autoimmune diseases in an Italian population of children with coeliac disease. Aliment Pharmacol Ther. 2007 Nov; 26(10):1409-17.
23 Ertekin V, Tosun MS, Erdem T. Screening of celiac disease in children with alopecia areata. Indian J Dermatol. 2014 May;59(3):317.

24 Peters JB, Warren MP. Reversible alopecia associated with high blood mercury levels and early menopause: a report of two cases. Menopause. 2019 Aug;26(8):915-8.

25 Kaufman JP. Letter: telogen effluvium secondary to starvation diet. Arch Dermatol. 1976 May;112(5):731.

26 Goette DK, Odom RB. Alopecia in crash dieters. JAMA. 1976 Jun;235(24):2622-3.

27 Krusinski PA. Letter: telogen effluvium secondary to weight loss and therapy with chorionic gonadotropin. Arch Dermatol. 1976 Apr;112(4):556.

28 Perez-Mora N, Goren A, Velasco C, Bermudez F. Acute telogen effluvium onset event is associated with the presence of female androgenetic alopecia: potential therapeutic implications. Dermatol Ther. 2014 May-Jun;27(3): 159-62.

29 Rudnicka L, Rakowska A. The increasing incidence of frontal fibrosing alopecia. In search of triggering factors. J Eur Acad Dermatol Venereol. 2017 Oct;31(10):1579-80.

30 Moreno-Arrones O, Saceda-Corralo D, Rodrigues-Barata A, et al. Risk factors associated with frontal fibrosing alopecia: a multicenter case-control study. Clin Exp Dermatol. 2019 Jun;44(4):404-10.

31 Bonaccio M, Pounis G, Cerletti C, Donati MB, Iacoviello L, de Gaetano G; MOLI-SANI Study Investigators. Mediterranean diet, dietary polyphenols and low grade inflammation: results from the MOLI-SANI study. Br J Clin Pharmacol. 2017 Jan;83(1):107-13.

32 Minihane AM, Vinoy S, Russell WR, Baka A, Roche HM, Tuohy KM, et al. Low-grade inflammation, diet composition and health: current research evidence and its translation. Br J Nutr. 2015 Oct;114(7):999-1012.

33 Zamora-Ros R, Andres-Lacueva C, LamuelaRaventós RM, Berenguer T, Jakszyn P, Barricarte A, et al. Estimation of dietary sources and flavonoid intake in a Spanish adult population (EPIC-Spain). J Am Diet Assoc. 2010 Mar;110(3):390-8.
Role of Diet as Adjuvant Treatment in Scarring and Nonscarring Alopecia
Skin Appendage Disord 2020;6:88-96 DOI: $10.1159 / 000504786$ 
34 Huh S, Lee J, Jung E, Kim SC, Kang JI, Lee J, et al. A cell-based system for screening hair growth-promoting agents. Arch Dermatol Res. 2009 Jun;301(5):381-5.

35 Messina M. Soyfoods and soybean phyto-oestrogens (isoflavones) as possible alternatives to hormone replacement therapy (HRT). Eur J Cancer. 2000 Sep;36 Suppl 4:S71-2.

36 Harada N, Okajima K, Arai M, Kurihara H, Nakagata N. Administration of capsaicin and isoflavone promotes hair growth by increasing insulin-like growth factor-I production in mice and in humans with alopecia. Growth Horm IGF Res. 2007 Oct;17(5):408-15.
37 Maslowski KM, Vieira AT, Ng A, Kranich J, Sierro F, Yu D, et al. Regulation of inflammatory responses by gut microbiota and chemoattractant receptor GPR43. Nature. 2009 Oct;461(7268):1282-6.

38 Tjellström B, Högberg L, Stenhammar L, Fälth-Magnusson K, Magnusson KE, Norin E, et al. Faecal short-chain fatty acid pattern in childhood coeliac disease is normalised after more than one year's gluten-free diet. Microb Ecol Health Dis. 2013 Sep;24:24.
39 Sytar O, Brestic M, Zivcak M, Tran LS. The Contribution of Buckwheat Genetic Resources to Health and Dietary Diversity. Curr Genomics. 2016 Jun;17(3):193-206.

40 Buckley JP, Kim H, Wong E, Rebholz CM. Ultra-processed food consumption and exposure to phthalates and bisphenols in the US National Health and Nutrition Examination Survey, 2013-2014. Environ Int. 2019 Oct; 131:105057.

41 Hashemipour M, Kelishadi R, Amin MM, Ebrahim K. Is there any association between phthalate exposure and precocious puberty in girls? Environ Sci Pollut Res Int. 2018 May; 25(14):13589-96. 